\title{
Sink Or Swim: The Development Of International Executives
}

\author{
Monika Renard, Florida Gulf Coast University, USA \\ Karen Eastwood, Florida Gulf Coast University, USA \\ Kay Tracy, Tracy and Associates, USA
}

\begin{abstract}
The increasing globalization of business has placed demands on executives to become more effective in understanding, appreciating, and dealing with differences in business practices, customs, and cultures around the world. This four-day seminar assists executives in this internationalization. It trains the participants in country investigation and research, has the executives design web pages for internationalization for a hypothetical company, Great Otter Lodge and Water Park, and requires participants to develop and deliver a training module for what they would need to know as they "get off the plane" in an overseas location.
\end{abstract}

Keywords: international management; international business; executive training; exercise

\section{INTRODUCTION}

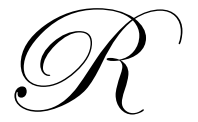

ising globalization has placed demands on business executives as organizations enter the world of international trade. As more companies decide to internationalize, it becomes increasingly important to develop executives' ability to research opportunities in other countries, develop their knowledge of country information sources, design an overseas presence, and understand cultural differences they will experience as they travel to overseas locations. Unfortunately, though many larger companies offer some sort of overseas training for their expatriates, those firms that provide extensive cross-cultural training and development to their executives are in the minority. Even organizations that do provide some training still experience a large failure rate. Therefore, we have developed program for executives to improve their understanding of such issues to improve their ability to operate successfully in the international arena.

\section{THE SEMINAR}

The seminar familiarizes participants who have little to no international experience with "know how" as to what is important in an overseas assignment. We allow four days. Part 1 trains the participants in country investigation and research. It asks the participant groups to investigate a set list of country differences and then present their findings in a spreadsheet to allow comparisons among the countries. Part 2 has the students develop web pages that present relevant information for an assigned company's overseas experience. Part 3 requires the participant groups to develop and deliver a 1-hour training session for the other participants about what they would need to know as they arrive in that overseas location. The goal of this part is to provide the executives with the training they need to enter an overseas country with the least amount of culture shock possible.

\section{Participants and Procedure}

The timing and activities for the seminar are given in Appendix A. We limit attendance to a maximum of 15 participants, who form 3-person groups. All participants must have individual computers with internet access. Each group chooses a target country from the list provided: Brazil, China, Dubai, India, New Zealand, and Nigeria. These countries were chosen as representative of various cultural and economic differences around the world. All groups are told to assume they are employed by Great Otter Lodge and Water Park to investigate expansion into their assigned country. They can refer to Great Wolf Lodge's website at www.greatwolf.com for information about a similar company. 


\section{$\underline{\text { Part } 1}$}

\section{Researching Country Information}

Part 1 helps participants develop the internet research skills necessary to find information, put it into a usable format, and understand differences in various countries. The groups are given some specific country items to research. The items include such things as infrastructure, government, culture, and workforce statistics. Table 1, Required Country Items to Investigate, below, shows some sample items. Groups are encouraged to search for other information relevant to their chosen country.

Table 1: Required Country Items to Investigate

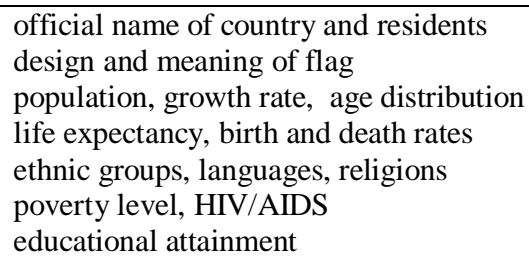

Each group submits a completed spreadsheet and we compile all of the information across countries. (See an example of a partial spreadsheet in Appendix B, Global Comparisons Spreadsheet.) The entire class is then able to compare countries and understand the relationship between facts such as median age, population growth rate, income, education; and life expectancy. They use this comparative information to assess the appropriateness of expansion into that country.

\section{$\underline{\text { Part } 2}$}

\section{Web Page Design}

We present important components and considerations for international web page design. For this lecture we draw from the work done by U.S. Export Assistance Center (Tracy, 2010). You can references this website at: http://export-u.com/. (Registration is free.) Once signed in, choose item 10, Website Globalization, a 3-part webinar.

Webinar part 10A introduces the concept of website globalization, describes how simple enhancements can increase your website's appeal to international visitors, and considers the pros and cons of website translation. Webinar part 10B considers international website promotion, and introduces the concepts of website internationalization and localization. Webinar part 10C provides a high-level overview of international e-commerce. (Runtimes: A- 23:54, B- 28:08, C- 12:16 minutes) (Tracy, 2010).

Participants design (on paper) the elements of a web page for Great Otter Lodge and Water Park appropriate to their chosen country following the design elements discussed in the lecture. They prepare and present a 10-minute review of their web page designs to the whole group.

\section{$\underline{\text { Part } 3}$}

\section{Developing and Presenting Training Sessions}

Parts 1 and 2 give the executives the knowledge they require to develop training sessions composed of brief interactive training modules specific to their countries. The sessions are intended to prepare the other executives in the seminar to arrive in the host country ready to begin successful business interactions. The modules are based on active learning practices with hands-on exercises, games, and creative activities, and are designed to increase participation and interest. 
Each group of three plans and delivers a 1-hour session based on information about its country. Each of the three individual group members develops and conducts training in an important knowledge area of the country. Some examples are: culture, language, and communication styles; negotiation techniques; greetings, business cards and gift-giving; or business etiquette. We have seen groups cook foods from the country, develop board games, demonstrate (temporary) tattooing, modify games from the internet, and work on arts and craft projects (e.g., personalized license plate in Arabic).

Group training sessions begin with a 10-minute introduction by the presenting team, which has set up a separate station for each of its three training modules. Following the introduction, the other participants rotate in groups of four from module to module in 15-minute intervals. Thus, each training module is presented simultaneously three times and all participants experience each module.

\section{SUMMARY}

This approach has been well received by the participants and leaves them with a memorable experience. Whether they have experienced negotiating tactics, basic language training, or foods from that country, all of the executives leave with a better understanding of global business in general, research skills and sources for countryspecific information, and an appreciation for the impact of cultural differences.

\section{AUTHOR INFORMATION}

Dr. Monika Renard earned her Ph.D. in Human Resources from the University of Maryland. Dr. Renard is an Associate Professor at Florida Gulf Coast University, Fort Myers, FL where she teaches a wide variety of human resource topics, negotiation, and international management. Dr. Renard is also the Director of FGCU's Conflict Management Institute. Her research interests include human resources and international management.

Dr. Kay Blythe Tracy earned her Ph.D. in Organizational Behavior from the University of Maryland, College Park. She has taught there and at Gettysburg College, Gettysburg, PA. Dr. Tracy is currently affiliated with Uni versity of Maryland-University College, and does consulting work in Organizational Behavior for Lagniappe Unlimited in Sarasota, FL. Her research interests include entrepreneurship and international management.

\section{REFERENCES}

1. Great Wolf Lodge. Accessed October 9, 2010 from: http://www.greatwolf.com/grapevine/explore/activities?s_kwcid=TC\%7C15979\%7Cwater\%20park\%7C\% 7CS\%7Cb\%7C5075375840

2. Tracy, George. (2010). Export-U Session 10A: Website Globalization. U.S. Export Assistance Center. Accessed October 9, 2010 from: http://exportu.com/website/login?area=webinar\&page=html/10a__website_globalization.html 


\section{APPENDIX A}

Timeline for Session

\begin{tabular}{|c|c|c|}
\hline Day and Time & Activity & Instructor Action \\
\hline \multicolumn{3}{|l|}{ Day 1.} \\
\hline 9-10:30 am & Intro, self, class participants, syllabus & \\
\hline $10: 30-11 \mathrm{am}$ & Break & \\
\hline $11-12: 30$ & Decide groups, choose countries, introduce company & \\
\hline $12: 30-1: 30$ & Lunch & \\
\hline $1: 30-3: 30$ & Investigate country, prepare group spreadsheet. & \\
\hline \multirow[t]{2}{*}{$3: 30-4$} & Turn in spreadsheet, discussion & \\
\hline & & $\begin{array}{l}\text { Compile comparative spreadsheet for } \\
\text { discussion on day } 2 \text {. }\end{array}$ \\
\hline \multicolumn{3}{|r|}{ ( } \\
\hline 9-10:30 am & $\begin{array}{l}\text { Comparative spreadsheet discussion. Introduce web } \\
\text { page component }\end{array}$ & \\
\hline $10: 30-11 \mathrm{am}$ & Break & \\
\hline $11-12: 30$ & Lecture on web page elements & $\begin{array}{l}\text { Bring PowerPoint slides for lecture. Also } \\
\text { bring sample web page designed with } \\
\text { correct elements. }\end{array}$ \\
\hline $12: 30-1: 30$ & Lunch & \\
\hline $1: 30-3: 30$ & Work on web page design & \\
\hline $3: 30-4$ & Discussion & \\
\hline \multicolumn{3}{|l|}{ Day 3} \\
\hline 9-10:30 am & Presentation of web page designs & $\begin{array}{l}\text { Insure appropriate technology is available } \\
\text { for student use. }\end{array}$ \\
\hline $10: 30-11 \mathrm{am}$ & Break & \\
\hline $11-12: 30$ & Introduction to training modules & \\
\hline $12: 30-1: 30$ & LUNCH & \\
\hline $1: 30-3: 30$ & Development of training modules & \\
\hline $3: 30-4$ & Discussion & $\begin{array}{l}\text { Remind students to bring anything they } \\
\text { need to present their training modules } \\
\text { tomorrow }\end{array}$ \\
\hline \multicolumn{3}{|r|}{ 皮 } \\
\hline 9-9:15 am & Preparation & \\
\hline $9: 15-10: 15$ & Group 1 presentation and training & \\
\hline $10: 15-11: 15$ & Group 2 presentation and training & \\
\hline $11: 15 \mathrm{am}-12: 15 \mathrm{pm}$ & LUNCH & \\
\hline $12: 15-1: 15 \mathrm{pm}$ & Group 3 & \\
\hline $1: 15-2: 15 \mathrm{pm}$ & Group 4 & \\
\hline $2: 15-2: 30 \mathrm{pm}$ & BREAK & \\
\hline $2: 30-3: 30 \mathrm{pm}$ & Group 5 & \\
\hline $3: 30-4: 00 \mathrm{pm}$ & Wrap up and feedback to instructors & $\begin{array}{l}\text { Bring instructor and seminar evaluation } \\
\text { forms }\end{array}$ \\
\hline
\end{tabular}




\section{APPENDIX B}

Global Comparisons Spreadsheet

\begin{tabular}{|c|c|c|c|c|c|c|}
\hline & BRAZIL & CHINA & DUBAI & INDIA & NEW ZEALAND & NIGERIA \\
\hline $\begin{array}{l}\text { The country's } \\
\text { official } \\
\text { national name } \\
\text { is }\end{array}$ & $\begin{array}{l}\text { Republica } \\
\text { Federativa do } \\
\text { Brasil (Brasil) }\end{array}$ & $\begin{array}{l}\text { People's Republic } \\
\text { of China }\end{array}$ & $\begin{array}{l}\text { United Arab } \\
\text { Emirates }\end{array}$ & Republic of India & Aotearoa & $\begin{array}{l}\text { Federal Republic } \\
\text { of Nigeria }\end{array}$ \\
\hline $\begin{array}{l}\text { A citizen of } \\
\text { this country is } \\
\text { properly } \\
\text { referred to as a } \\
\text { (an) }\end{array}$ & Brazilian & Chinese & Emiratis & Indian & $\begin{array}{l}\text { New Zealander, } \\
\text { Kiwi (colloquial) }\end{array}$ & Nigerian \\
\hline $\begin{array}{l}\text { The population } \\
\text { is growing at a } \\
\text { per year rate of }\end{array}$ & $1.199 \%$ & $.655 \%$ & $4.9 \%$ & $1.548 \%$ & $0.935 \%$ & $1.999 \%$ \\
\hline $\begin{array}{l}\text { The life } \\
\text { expectancy for } \\
\text { residents in } \\
\text { years is }\end{array}$ & 71.99 & 73.47 & 75.24 & 69.89 & 80.36 & 46.94 \\
\hline $\begin{array}{l}\text { The major } \\
\text { languages } \\
\text { spoken are }\end{array}$ & \begin{tabular}{|l|} 
\\
Portuguese. \\
Less common: \\
Spanish (border \\
areas and schools), \\
German, Italian, \\
Japanese, English, \\
and a large number \\
of minor \\
Amerindian \\
languages
\end{tabular} & $\begin{array}{l}\text { Standard Chinese } \\
\text { or Mandarin } \\
\text { (Putonghua, } \\
\text { Beijing dialect), } \\
\text { Yue (Cantonese), } \\
\text { Wu } \\
\text { (Shanghainese), } \\
\text { Minbei (Fuzhou), } \\
\text { Minnan } \\
\text { (Hokkien- } \\
\text { Taiwanese), } \\
\text { Xiang, Gan, } \\
\text { Hakka dialects, } \\
\text { minority } \\
\text { languages }\end{array}$ & $\begin{array}{l} \\
\text { Arabic, } \\
\text { English, } \\
\text { Persian, Hindi, } \\
\text { Urdu }\end{array}$ & $\begin{array}{l}\text { Hindi } 41 \% \text {, Bengali } \\
8.1 \% \text {, Telugu 7.2\%, } \\
\text { Marathi 7\%, Tamil } \\
5.9 \% \text {, Urdu 5\%, } \\
\text { Gujarati } 4.5 \% \text {, } \\
\text { Kannada 3.7\%, } \\
\text { Malayalam 3.2\%, } \\
\text { Oriya 3.2\%, Punjabi } \\
2.8 \% \text {, Assamese } \\
1.3 \% \text {, Maithili 1.2\%, } \\
\text { other 5.9\% }\end{array}$ & $\begin{array}{l}\text { English (official), } \\
\text { Maori (official), } \\
\text { Sign Language } \\
\text { (official) }\end{array}$ & $\begin{array}{l}\text { English } \\
\text { (official), } \\
\text { Hausa, Yoruba, } \\
\text { Igbo (Ibo), } \\
\text { Fulani }\end{array}$ \\
\hline
\end{tabular}




\section{NOTES}

